\title{
A BELATED RECORD OF CANADA LYNX SOUTH OF THE BOREAL FOREST DURING THE MID-CONTINENTAL IRRUPTION OF 1962-1963
}

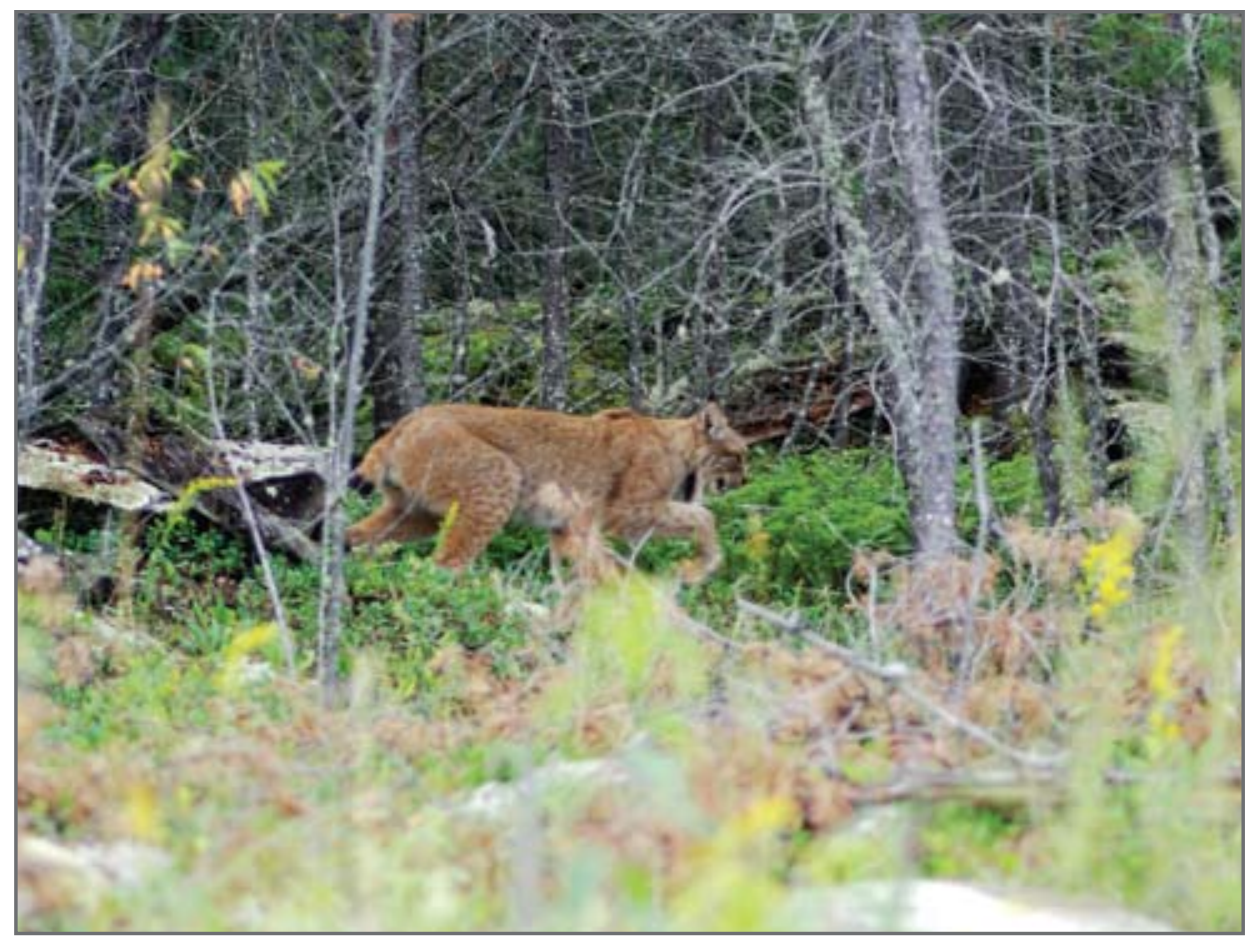

Canada Lynx south of Black Lake, Nopiming Provincial Park, Manitoba, August 2, 2010 Photo credit: Christopher Staniforth

\section{Spencer G. Sealy}

Department of Biological Sciences

University of Manitoba

Winnipeg, MB R3T 2N2

Spencer.Sealy@umanitoba.ca

An unprecedented number of Canada Lynx (Lynx Canadensis) were recorded south of the boreal forest across the Canadian Prairie Provinces and north-central United States in 1962-1963, with additional records extending into $1964 .{ }^{1}$ Canada Lynx were recorded during this irruption in the grassland regions of southern Alberta, Saskatchewan and Manitoba ${ }^{1,2-4}$, as well as Minnesota ${ }^{5}$, Montana ${ }^{6}$, North Dakota7 ${ }^{7}$ and south to lowa. ${ }^{8}$

For the record, I document another observation, long buried amid field notes, of a Canada Lynx observed in southern Alberta in late spring 1963, within the span of this irruption. From early May through mid-September 1963 and 1964, I assisted wildlife biologists associated with the Fish and Wildlife Division of the Alberta Department of Lands and Forests. In both years, I worked primarily out of Brooks, Alberta, through early July each year, eartagging Pronghorns (Antilocapra americana) and monitoring Canada Goose (Branta canadensis) and other waterfowl populations. During the remainder of both summers I conducted brood surveys of Gray Partridge (Perdix perdix), Ring-necked Pheasant (Phasianus colchicus) and Greater Sage-Grouse (Centrocercus urophasianus), and participated in aerial surveys of Pronghorns. These and other activities took me at various times to all regions of southern Alberta.

On June 19, 1963, while observing nesting American Avocets (Recurvirostra americana), a Canada Lynx appeared suddenly from the vegetation at the edge of a nearly dry slough, about $6 \mathrm{~km}$ west of Cassils $\left(50^{\circ} 35^{\prime \prime} 12^{\prime} \mathrm{N}, 112^{\circ} 2^{\prime \prime} 9^{\prime} \mathrm{W}\right)$, or 16 km west of Brooks, Alberta. The lynx stood silently about $25 \mathrm{~m}$ in front of me before it walked slowly away and disappeared about 30 seconds later behind a patch of dead Cattail (Typha latifolia). It did not re-appear during the several minutes I waited, motionless, and I did not follow it or otherwise attempt to locate it again. There were no trees around or in the vicinity of the slough. An undated record of a lynx killed near Brooks in $1963^{4}$ may have been the individual observed above.

My immediate reaction to the presence of this felid was that it was a Bobcat (L. rufus), considering that the site was within its known range in southern Alberta. With my binoculars trained on the individual for about 20 seconds, I was able to record a general lack of spots in the pelage and the presence of black hairs on the tip of the tail, which are among the characteristics of Canada Lynx ${ }^{9}$, but I did not obtain a photograph that would have substantially increased the value of the record. ${ }^{10}$ I had previously seen only one Canada Lynx, and had skinned one road-killed individual, but I had never observed a Bobcat.

This was the only Canada Lynx I observed in southern Alberta in 1963 and 1964, and no Bobcats were observed. I realized at the time that the observation of a lynx so far out on the prairies was unusual, but it was not until later that I became aware that there had been a mid-Continental irruption of this species that year and many lynx had been reported across the prairie region.

Published reports of Canada Lynx in southern Saskatchewan began appearing in Blue Jay when one was observed near Maryfield ${ }^{11}$ and two individuals were reported near Beechy, 
one of which was killed in a snare. ${ }^{2}$ Reports of more than two dozen lynx observed or shot in southern Saskatchewan and Alberta followed, through 1966. Up to 50 lynx were captured in the Calgary area, 36 of them within the city's boundaries, between March 18 and November 3, 1963. ${ }^{12}$ Many of those lynx were sent to zoos around the world. Stomach contents of two lynxes sampled during this irruption, one from an individual taken at Calgary, the other taken near Brooks, revealed opportunistic use of prey available on the grasslands: Richardson's Ground Squirrel (Urocitellus richardsonii) and Gray Partridge, respectively. ${ }^{4}$

The most comprehensive account of this irruption, accompanied by maps and photographs, focused on the occurrences of Canada Lynx in North Dakota, beginning in 19611962.7 About 200 individuals were shot, trapped or otherwise killed, predominantly in the northeastern counties of the State. Most individuals were identified as adults, but putative family groups were observed and some juveniles were killed, which suggested that some individuals had reproduced. ${ }^{7}$ By contrast, most individuals examined in the Calgary region were identified as young adults ${ }^{12}$, although this was not confirmed. From these observations the question arises of whether most or any of the dispersing individuals returned or would have returned to the boreal forest after conditions had changed.

The movements by Canada Lynx into unfamiliar prairie habitats occurred at a different time, when lynx and other large predators were generally looked upon as liabilities, and many of the lynx were killed. We live in a more enlightened era now, and recognition of the importance of large predators in our ecosystems has resulted in the removal of most bounties and increased legal protection.

\section{Epilogue}

The merit of publishing another anecdotal record of Canada Lynx obtained more than 50 years ago during a major and well-documented invasion of the prairies may seem questionable. Indeed, the record was among dozens reported - many of individuals trapped and shot — that does not add another locality of occurrence, because another or the same lynx was taken in the Brooks area of southern Alberta about the same time. ${ }^{4}$ This record would have been among the many others, however, that were emerging at the same time, revealing that a major invasion of Canada Lynx was underway, if it had been published in the months immediately closer to the time of the observation. The movements of this large predator on to the grasslands in the early 1960s was adequately documented with captures of live animals and specimens, which constitute the most reliable occurrence data for rare or elusive species. ${ }^{10}$ Anecdotal records of occurrence, that is, unverifiable observations or their sign, are given much less weight as evidence of occurrence. ${ }^{10}$ Nevertheless, the scattered visual records, placed against a back-drop of specimens ${ }^{13}$, contributed to the documentation of the extent of the movements of the lynx in time and space.

Anecdotal occurrence data (unverifiable observations of organisms or their sign) are ranked low in a list of evidentiary standards that are useful in documenting occurrence of rare or elusive species. ${ }^{10}$ This ranking was used recently in an assessment of the status of Canada Lynx populations on the Alaska Peninsula, with visual observations - historical and recent - augmenting the more valuable specimen and photographic records. ${ }^{13}$ The characteristics of the lynx invasion considered here were documented from the most reliable evidence (i.e., specimens and identifiable photographs of the animals and their sign).

\section{Acknowledgements}

I gratefully acknowledge the opportunity to have worked with wildlife biologists and conservation officers associated with the Fish and Wildlife Division of the Alberta Department of Lands and Forests in the early 1960s. Michael Swanson of the Chester Fritz Library, University of North Dakota, and Heather Northcott, Provincial Archives of Alberta, provided copies of important articles. Richard J. Staniforth provided the photograph of the Canada Lynx, which was taken by Christopher Staniforth

1. Gunderson HL (1978) A mid-continental irruption of Canada Lynx, 1962-63. Prairie Naturalist 10:71-80.

2. Santy D (1964) Some interesting lynx observations. Blue Jay 22:35.

3. [Ledingham GF, Belcher M, Nero RW] (1964). [Editorial] Comments on lynx invasion. Blue Jay 22:35-36.

4. van Zyll de Jong CG (1966) Food habits of the lynx in Alberta and the Mackenzie District, N.W.T. Canadian Field-Naturalist 80:18-23.

5. Mech LD (1973) Canadian Lynx invasion of Minnesota. Biological Conservation 5:151-152.

6. Hoffman RS, Wright PL, Newly FE (1969)

The distribution of some mammals in

Montana. I. Mammals other than bats. Journal of Mammalogy 50:579-604.

7. Adams AW (1963) The lynx explosion. North Dakota Outdoors 26:20-24.

8. Rasmussen J (1969) A recent record of the lynx in lowa. Journal of Mammalogy 50:370371.

9. Naughton D (2012) The Natural History of Canadian Mammals. Canadian Museum of Nature, Ottawa, and University of Toronto Press, Toronto, ON

10. McKelvey KS, Aubry KB, Schwartz MK (2008) Using anecdotal occurrence data for rare or elusive species: The illusion of reality and a call for evidentiary standards. BioScience 58:549-555.

11. Bullock M (1963) The lynx. Blue Jay 21:76.

12. MacEwan G (1964) Our natural heritage: Lean year for the lynx. Calgary Herald Magazine, Saturday, 1 February 1964, page 2.

13. Watts DE, Olson LE (2016) Recent records of lynx on the Alaska Peninsula. Northwestern Naturalist 97:124-129. 